\title{
Intercultural Creativity and Exploration through Gamelanistic Elements in Marzelan Salleh's Puteri Gunung Ledang and John Cage's Dream
}

\section{Criatividade intercultural e exploração por meio de elementos gamelanísticos em Puteri Gunung Ledang de Marzelan Salleh e Dream de John Cage}

\author{
(iD) Camellia Siti Maya Mohamed Razali \\ Universiti Putra Malaysia, Malaysia \\ camellia@upm.edu.my
}

iD (9) Marzelan Salleh²

University of Malaya, Malaysia

marzelan@um.edu.my

\begin{abstract}
1 Camellia Siti Maya Mohamed Razali is currently a lecturer at the Department of Music, Universiti Putra Malaysia. Camellia received her PhD from the University of Bristol, under the supervision of Prof. Dr. Michael Ellison. Camellia's music are inspired by Asian nuance and Western European music combined through transcultural contemporary ideas. Her interest in music composition lies in composing for contemporary acoustic orchestral, chamber and vocal music. Her music have been performed in United Kingdom and Malaysia. Performances of her compositions at major international music festivals and concerts include Bristol New Music Festival, Contemporary Music Venture Concert Series and University of Bristol's New Music Ensemble Concerts. Camellia Mohamed Razali has worked and collaborated with prestigious music ensembles and musicians namely, Ensemble Variances, Quatuor Bozzini, New Music Ensemble, Narden Sonel, and Luis Ingels, to name a few. She has attended composition workshops and masterclasses by renowned composers such as Pierre Boulez, Sir Peter Maxwell Davies, John Pickard, Trevor Wishart, Phillip Glass and Nigel Clarke. While studying in Bristol, her composition, Sayup, for 11 instruments won the New Music Ensemble Call for Scores in 2015.

Since 2016, she has presented papers and written book chapters concerned with addressing through music, the possibilities and questions raised by music and text, colliding and interacting cultures in today's world. At the moment her research, both in composition and writing has brought upon new music compositions such as Wahyu and Prosa Air Mata, both compositions combining music and Malay poetry, and both being performed in the United Kingdom in 2016. Her book chapter entitled, "Space and Spacing's in Toru Takemitsu's Rain Tree Sketch and Marzelan Salleh's Melayang"recently won Best Creative Writing in STEdex 2017.

2 Marzelan Salleh has lived in Malaysia and UK. His music such as Bani Jawi, Bangkit, Puteri Gunung Ledang, Rukun, Hijrah, and Tarian Cinta have been inspired by contemporary music methods deriving from diverse nuances of Asian music. His music has been performed in United Kingdom and Malaysia alongside composers such as John Pickard, Michael Ellison, and Dieter Mack. Performances of his compositions at major international music festivals and concerts include New Music in the South West, Bristol New Music Festival, Contemporary Music Venture Concert Series and University of Bristol's New Music Ensemble Concerts. Marzelan Salleh has worked and collaborated with prestigious music ensembles and musicians namely, Quatuor Bozzini, the Brodowski Quartet, New Music Ensemble Bristol, and Manos Charalabopoulos, to name a few. Marzelan Salleh has attended composition workshops and masterclasses by renowned composers and musicians such as Pierre Boulez, Sir Peter Maxwell Davies, John Pickard, Trevor Wishart, Philip Glass, and Nigel Clarke. Marzelan Salleh received his PhD in Composition from the University of Bristol under the supervision of Prof. Dr. Michael Ellison, and previously did his Masters in Composition at the University of Salford with Prof. Alan Williams. Marzelan Salleh's first involvement in music began as a saxophonist in St. John Institution Kuala Lumpur's marching band. After which he enrolled into Universiti Teknologi MARA Malaysia, where he studied clarinet and obtained a first class degree. Composing music has always been his main interest, which led him to obtain a scholarship to pursue contemporary music composition in the UK. Currently, Marzelan Salleh is a senior lecturer at the Cultural Centre, University of Malaya.
\end{abstract}




\begin{abstract}
Intercultural activity especially through music is widespread and relevant to Malaysian current times. The abundance of music compositions labeled intercultural since the 1900s clearly proves its effectiveness and strength as society continues to embrace them. The emergence of young and new contemporary composers contributes to the advancement of musical ideas and updated knowledge towards contemporary music compositions both locally and internationally. Through them, intercultural resources and tools for composing from various cultures are explored in creative ways. This article discusses the composition of two piano works from Marzelan Salleh, a Malaysian composer, and the late John Cage, an American composer. Both explore the possibilities, intentionally or unintentionally, of combining contrasting influences of Asian traditional music idiom with Western traditional and contemporary compositional techniques into personal musical expressions.
\end{abstract}

Keywords: composition, contemporary music, intercultural, composition techniques

Resumo: A atividade intercultural, especialmente por meio da música, é amplamente difundida e relevante para os tempos atuais da Malásia. A abundância de composições musicais rotuladas como interculturais desde 1900 prova claramente sua eficácia e força à medida que a sociedade continua a abraçá-las. O surgimento de jovens e novos compositores contemporâneos contribui para o avanço das ideias musicais e do conhecimento atualizado para composições musicais contemporâneas, tanto local quanto internacionalmente. Através deles, recursos interculturais e ferramentas para compor de várias culturas são explorados de maneiras criativas. Este artigo discute a composição de duas obras para piano, (uma)* de Marzelan Salleh, um compositor malaio, e (outra)* do falecido John Cage, um compositor americano. Ambos exploram as possibilidades, intencionalmente ou não, de combinar influências contrastantes do idioma da música tradicional asiática com técnicas composicionais tradicionais e contemporâneas ocidentais em expressões musicais pessoais.

Palavras-chave: composição, música contemporânea, intercultural, técnicas de composição.

Recebimento: 15/08/2020

Aceito em: 28/09/2020 


\section{Introduction}

Marzelan Salleh in his PhD dissertation explores the questions and identification of intercultural in his music compositions. He proceeds to explain that intercultural compositions begin when musical elements of at least two different cultures are integrated into a work without limiting the belonging of the composer to any culture presented in the work. Instances when the composer and all musical elements originate from the same culture, then the manner of performance and presentation of the work on an international platform and its relevance to the external community is an important aspect of intercultural music as well. This goes in agreement with J.H. Kwabena's explanation of "interculturalism as the process of identifying with or sharing in the heritage of other cultures with a view to broadening one's cultural horizon or one's capacity to understand and appreciate differences in modes of expression." (Wiggins, 2005)

Marzelan Salleh is a contemporary Malaysian composer whose life illustrates the experience of a Malaysian composer whose creativity and imagination has been shaped by a multicultural environment. Due to his exposure to the Western classical music tradition, he is rooted in two music cultures, which are music he experienced in Malaysia and music exposure while abroad. There are a lot of potential and limitless possibilities in incorporating internal and external influences into contemporary compositions. Hence, in Marzelan Salleh's point of view, there is an intimate correlation between 'art' and 'intercultural'. Modern Malaysian composers like him explore and dissect traditional music as they identify traditional music as sources for creative sounds, ideas, themes, and innovative compositional processes and techniques to enrich their compositions. He finds inspiration through the integration of traditional and foreign styles and expressions. Worthy of mention is his procedure of assimilating adopted foreign forms with traditional Malaysian and other Asian music elements in his 
Intercultural Creativity and Exploration through Gamelanistic Elements...

Camellia Siti Maya Mohamed Razali • Marzelan Salleh

music. This is a particular response exploring new dimensions in music by integrating elements from different cultures.

Malaysian and foreign elements are almost equivalently or equally dominantly present when addressing Marzelan's modern intercultural music. His music is a product of synthesis of two worlds and a result of personal experiences of different cultures. Marzelan always critically analyses his compositional processes before composing as most of his compositions are written as a result in creatively employing foreign musical concepts and procedures along with the influences of traditional elements and techniques.

\section{John Cage}

One of the most influential composers of contemporary music, John Cage was one of the leading figures of avant-garde and a pioneer of indeterminacy music. His musical works usually challenges musicians and audiences assumed definitions about musicianship and musical experiences. His musical works became controversial topics in composition, musicology and the art of performance. Cage's main influences originate from personal studies of East and South Asian cultures and philosophy. Inspired by thoughts and ideas of Indian philosophy, Zen Buddhism and the Chinese classic text I-Ching, John Cage began the conception of aleatoric music, controlled-chance music, and experimental music compositions. During his time as a composer, Cage composed profound music. Along with other avant-gardist composers, he was intent on breaking the rigid ideas of musical past. One of his important collaborators was Merce Cunningham, the dancerchoreographer and painter Robert Rauschenberg. Through their acquaintance, Cage experimented and created surreal sounds and music composed through chance. Cage's studies of either Zen Buddhism, Indian philosophy, exploration of aleatoric or chancecontrolled music, and consultations of the "I Ching," are used to free himself from having to choose (Jensen, 2009). 


\section{Background of Gamelan}

Since the first millennium, gamelan has developed in and has become associated mostly with Bali and Java. In the $19^{\text {th century, }}$ gamelan was also introduced and still cultivated in Malaysia (Tenzer \& Moja, 2011). Gamelan music is one of the traditional musics in Indonesia and Malaysia. Balinese gamelan and Javanese gamelan from Indonesia contrasts in character whereby Balinese gamelan is faster, brighter and more aggressive compared to Javanese gamelan, which is softer and more sensuous (Malm, 1996).

\section{Gamelan-influenced music}

There have been substantial gamelan influenced works written by composers mainly, Lou Harrison and Colin McPhee. Harrison's Concerto for Piano and Javanese Gamelan for example incorporates Javanese gamelan and the piano. The western instrument, the piano, acts as the quasi-soloist. In Harrison's concerto, the piano is tuned to the pitches of the gamelan. Harrison's concerto has three movements. His concerto has three movements as any traditional classical concerto. However, each movement contrasts in the Javanese scales used instead of difference in key. The first and last movement uses the slendro mode and the second movement uses the pelog mode with musical themes deriving from Balinese folk sources. Since the 1930s during his stay in Bali, McPhee's music were very much influenced by Balinese music and especially gamelan. His Tabuh-tabuhan for 2 pianos and orchestra showcases extensive influences of gamelan music. It is scored for a western orchestra combining Balinese and traditional Western musical elements. The 'nuclear gamelan' as McPhee describes is the central idea of this orchestral work consisting the sounds of two pianos, celesta, xylophone, marimba, and glockenspiel along with two Balinese gongs and cymbals, giving Tabuh-tabuhan its percussive consistency of sound, characteristic of gamelan music. 


\section{Why these two compositions?}

When Marzelan Salleh composed Puteri Gunung Ledang for solo piano, he intended from the beginning to utilize and transform the gamelan modes of slendro and pelog to fit into his piano work as means of showcasing ingenuity and creativity as part of his compositional exploration. As for John Cage's Dream there aren't any evidence showing his intended use of gamelan sounding pitches for his piano work. However, his use of suspended phrasings and time has resulted in the sustained resonance effect like the gamelan upon Dreams, which has been amplified further with his choice of pitches.

This article will look into two solo piano works by two composers. One composer has deliberately intended on writing gamelan infused work while another may have unintentionally written a gamelan-like work. Nevertheless, we will investigate how these gamelanistic features have been reproduced on a western music instrument. Solo piano works were chosen, as it will be fundamentally easier investigating their music on a single instrument compared to a large scale orchestral work.

\section{Notational Devices and Instrumental Resources of Puteri Gunung Ledang and Dreams}

Both composers, Marzelan Salleh and John Cage compose largely for Western musical instruments such as the piano and orchestra. John Cage extensively wrote for piano. Solo piano works by John Cage are broad and has been compiled in the C.F. Peters compilation album called 'Piano Works 1935-48'. However, Marzelan evokes traditional musical styles and nuances using Western instruments. Both Dream and Puteri Gunung Ledang are works for solo piano evoking a gamelan-like sound world and nuances, hinting at traditional musical styles and nuances using 
Western instruments. But in a typical gamelan ensemble the piano does not exist. The composers of both piano works have used the role of the piano in contrary to a traditional music ensemble. Whether intentionally or unintentionally, Marzelan Salleh's and John Cage's approach in both of these solo piano works may be viewed as reintroducing tradition in a contemporary form and meaning. This also reflects into the notational device chosen for Puteri Gunug Ledang and Dreams where the conventional Western music notation is used for both composers' works. There isn't a show of any extended techniques or innovative notation and performing ideas. It shows music notated in any way possible will always audibly sound as intended by the composer as long as the notation system employed is understood and produced according to the information given.

\section{Marzelan Salleh's Puteri Gunung Ledang}

\section{Elements of Gamelan: Melodic Colours and Musical Gestures}

Using only conventional musical notation. Marzelan Salleh aims to deliver a composition of totally Asian-sounding themes and motives without having any graphic or experimental music notation. He has chosen to highlight gamelan music in this solo piano composition to depict the legendary Javanese princess and her forbidden love with the Malay warrior, Hang Tuah.

In comparison, Malaysian gamelan shares a closer character to Javanese gamelan. The pitch organization for Puteri Gunung Ledang does not strictly adhere to any form of the gamelan modal systems but subtlety refers to them. The two modes used in Puteri Gunung Ledang are slendro and pelog, which are widely used in Malaysian and Indonesian gamelan music, although slendro is commonly associated with Malaysian gamelan and pelog with Indonesian gamelan. Slendro is a tuning and also a scale system involving 
Intercultural Creativity and Exploration through Gamelanistic Elements...

Camellia Siti Maya Mohamed Razali • Marzelan Salleh

five tones per octave, and pelog comprises five to seven tones per octave.

Puteri Gunung Ledang, the legendary Javanese princess from Indonesia is symbolized here in this solo piano work using the pelog scale while slendro scale will represent Hang Tuah. The slendro (Example 1) and pelog (Example 2) modes in Puteri Gunung Ledang are notated out below.

Ex. 1: Slendro

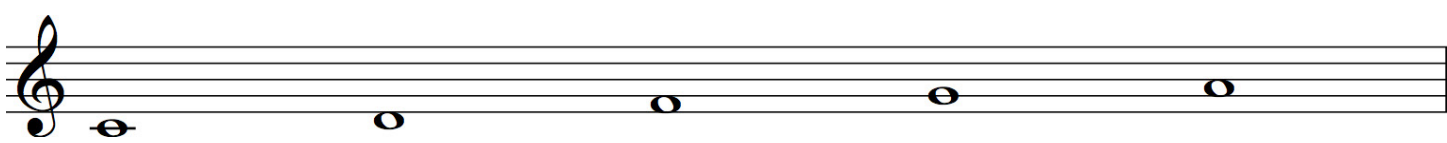

Ex. 2: Pelog

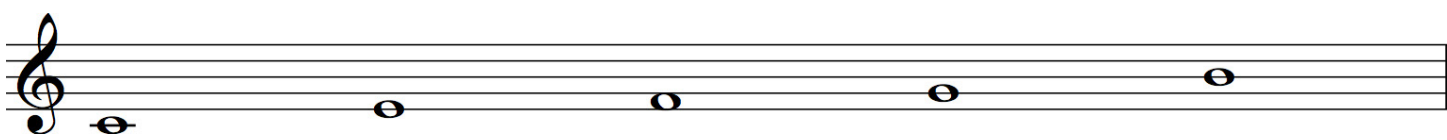

These two modes are used separately and at times together in juxtaposition or followed by one another in a dovetailing manner thus, creating harmonies or heterophony texture within this piece, instantly giving different sense of audible colours (Figure 1).

Fig. 1: Slendro and Pelog used together
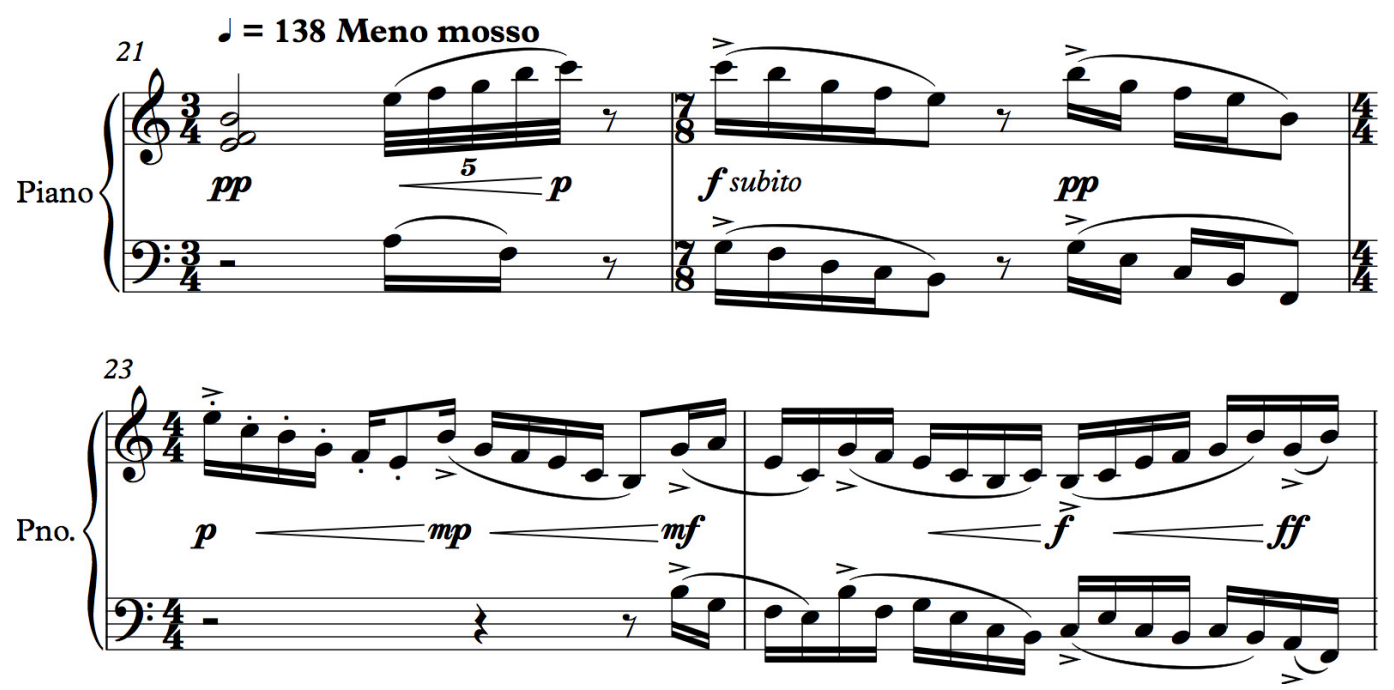
Intercultural Creativity and Exploration through Gamelanistic Elements...

Camellia Siti Maya Mohamed Razali • Marzelan Salleh

A gamelan ensemble consists of bonang, saron baron, saron peking, gender, slanten, kenong, gong, and gendang. A t bars $40-45$, quintuplets and semiquaver triplets run through a flurry of gamelan-like scales, accompanied in the bass clef by lower sounding punctuation notes similar to the sounds of a kenong in a Gamelan ensemble. These kenong accompaniments act as a counter-melody to the melody above (Figure 2). Kenongs are similar in shape to a bonang, but bigger, wider and taller. They are cradled individually on suspended cords in a rack. It is played by hitting its knob with a soft mallet, as it is a gong-like instrument, playing its role as the punctuating link between the gongs and the rest of the gamelan ensemble.

Fig. 2: Gamelan-like scales accompanied by kenong counter-melody
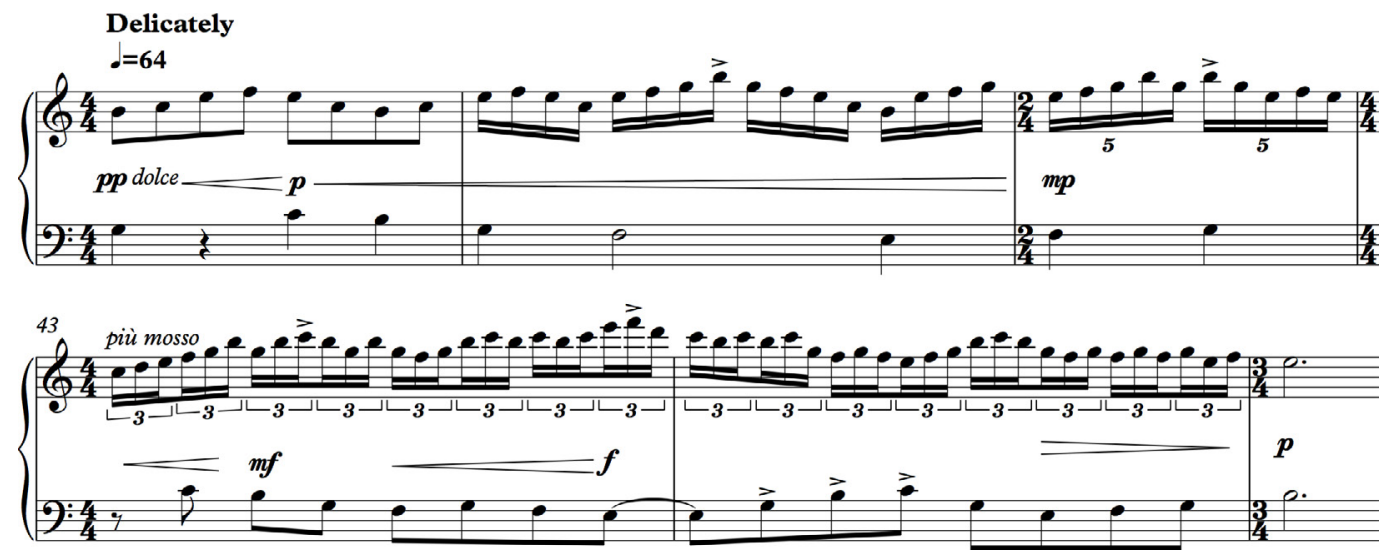

To create a more colouristic and dramatic quality to the music, Marzelan Salleh has added what he calls as 'note interferences', which are intuitive inflections not relating to any chromaticisms or tonality relations. These interferences come in the form of minor second intervals and tritone intervals to inflict tension deriving from the gamelan scales themselves (Figure 3). 
Intercultural Creativity and Exploration through Gamelanistic Elements...

Camellia Siti Maya Mohamed Razali • Marzelan Salleh

Fig. 3: Minor second and tritone intervals

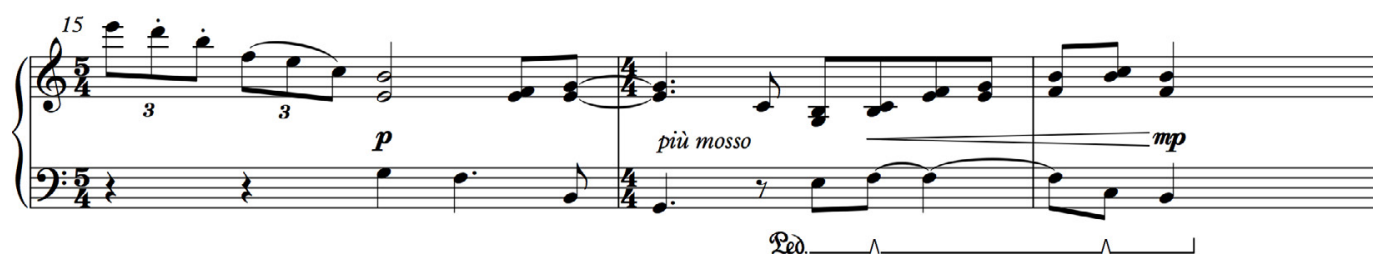

Even in the harmonies, these minor seconds and tritones are present to deliver darker colours in the music (Figure 4).

Fig. 4: Minor second and tritone intervals in the harmonies

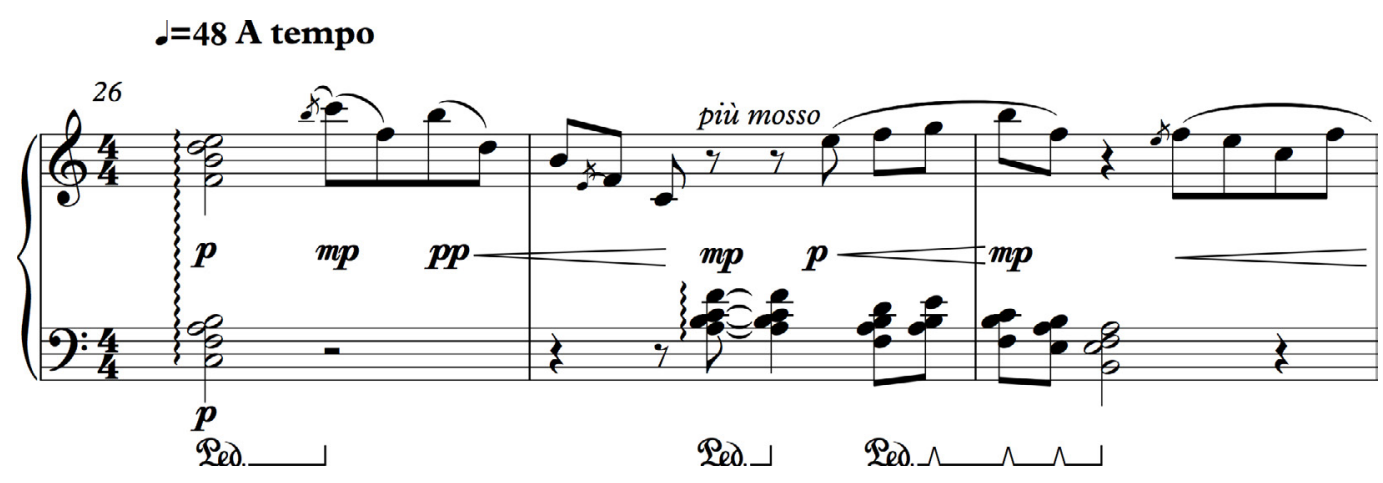

The sense of movement and direction in this solo piano piece is vital and requires compositional techniques such as considerations of tone colour, transposition, register, doublings, and dynamics. The overall form and structure of the pitch material is determined by the pitch organization of this piece. The two gamelan modes used in Puteri Gunung Ledang, slendro and pelog, are highlighted more efficiently through the use of transposition and replacing them into different registers of the piano, and the use of octave and unison doublings on particular group of pitches audibly connects the overall pitch structure of this piano composition. 


\section{John Cage's Dream}

Dream, a piano accompaniment to dance is a collaboration result with dancer Merce Cunningham. Essentially a single melodic line, Dream is written using a fixed range of tones, which are minimal fixed tones influenced by Balinese gamelan and forecasts through the I Ching.

Experimenting with the ways the sound of piano is projected in Dream is another highlight of this piece. For this piece, Cage points out, "Always with resonance; no silence; tones may be freely sustained, manually or with pedal, beyond notated duration." Dream's soft and lyrical sounds and meditative character arises from the sustained resonances produced either manually or with the piano's pedal. By sustaining tones through the entire piece, Cage manages to suspend time. There isn't any empty moments of silence for this piece, instead tones swirl and continue endlessly into one another creating ambiguity and clouds of sounds similar to a vague dream. The expressive and rhythmic freedom of tempo rubato in Dream helps the pianist to control the sustained tones all the time, even with the specific indicated metronome marking of $\square=88$, and the time signature of $2 / 2$.

\section{Form, Structure and Temporality}

The time signature for Dream is $2 / 2$, with the tempo marked $\mathrm{D}=$ 88. As a result of a collaboration and artistic partnership, Dream was originally written and used as music for dance. Dream follows the rhythmic dance structure of Merce Cunningham's choreography.

In gamelan music, even strict processes of repetition can transform through time. Michael Tenzer (2006) in his book describes, 
I call this discursive isoperiodicities, in that a single cyclic entity narrates, as it were, a journey through processes of temporal expansion and contraction developed and sanctioned by the culture. The ingenious manipulation of rhythmic motion, density, and tempo in gamelan is a central creative resource of gamelan music.

Gamelan music plays with our sense of time. As through Dreams unique approaches, John Cage is stretching and compressing its rhythm and tempo, leading the listener through several statements of the main phrase, followed by one statement of a differing phrase. Gamelan music is known to be temporally flexible and subjected to fluctuations in tempo and temporality. Meanwhile, processes of lengthening and shortening, also called as augmentation and diminution, does coordinate with the tempo to produce a musical form that is through composed. In gamelan music, repetition can be molded and transformed through time. Generally, the central character of gamelan music lies in its manipulations of rhythmic motion, density, and tempo.

As the title suggests, the dream-like quality of this piece owes to its uneven and incomplete phrasing (Figure 5). The phrasings of the pitches are irregular in length and this contributes to the lilting movements and a suspended sense of time created in the piece. 
Intercultural Creativity and Exploration through Gamelanistic Elements...

Camellia Siti Maya Mohamed Razali • Marzelan Salleh

Fig. 5: Dream, first page, uneven and incomplete phrasings

\section{DREAM}

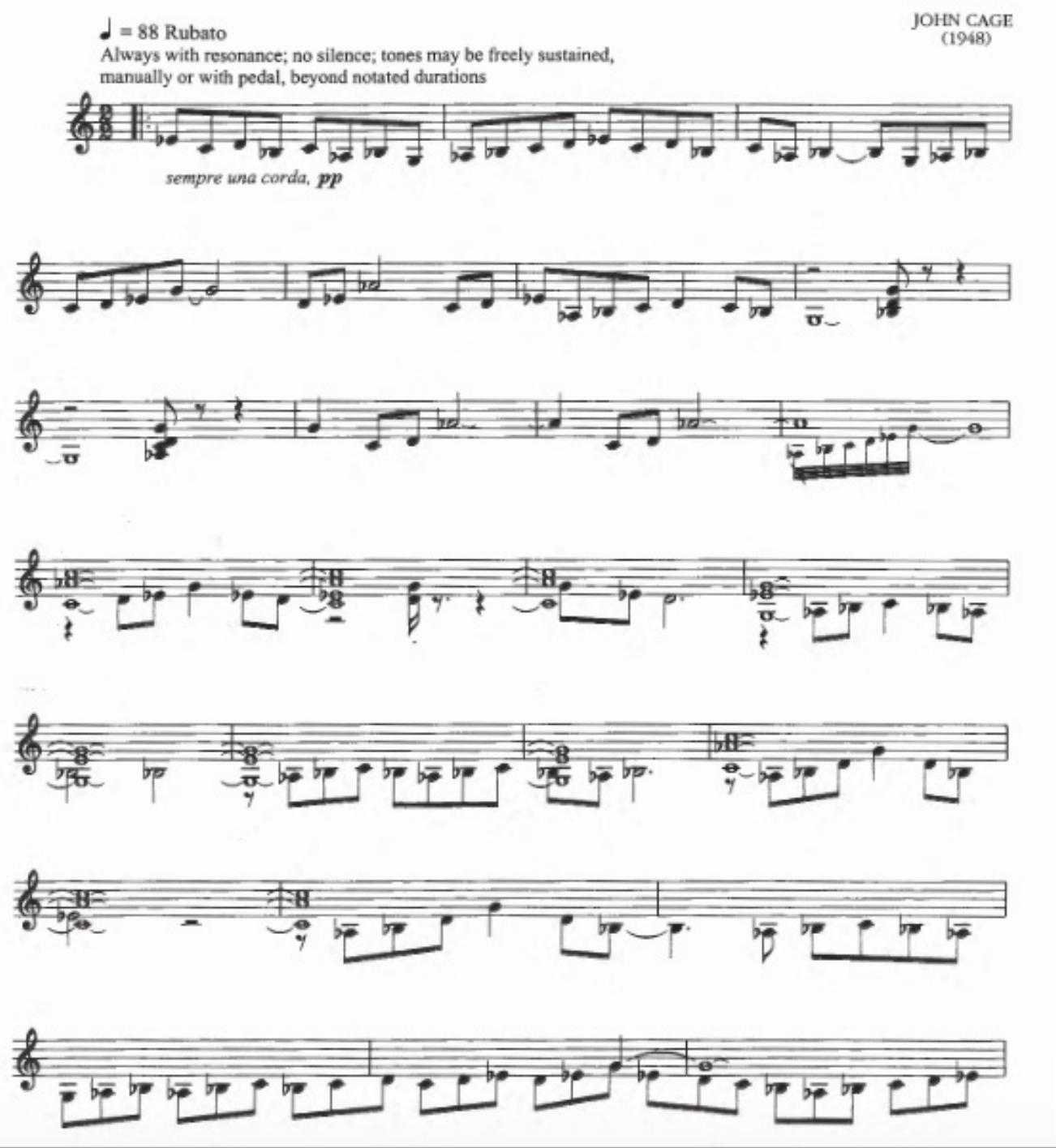

\section{Melodic Elements}

Although John Cage has rarely referenced gamelan in his music, he certainly heard it while studying and working with Henry Cowell in the early 1930s. There have been some affinities between some works of John Cage and the traditional gamelan music Jo, 
2015). Dreams in particular exists nuances referring to the sound world of gamelan music. Again, similarly to Marzelan Salleh's Puteri Gunung Ledang, John Cage's Dream is a subtle referencing towards gamelan pitch structures and inflections. Also, John Cage uses the solo piano, a Western instrument and not a traditional instrument to depict a different sound world of a different style, character and musical culture.

There are only six pitches in the scale used in John Cage's Dream (Example 3). These pitches in even quaver beats largely makes up the melodic content of Dream. As shown earlier in the discussion, the slendro and pelog scale of the gamelan mode is built upon five pitches compared to the scale in Dream, which has six pitches. Upon analysis, the scale used in Dream is identified to be the same as the pelog scale, but instead John Cage has added a perfect 4th into it (Example $4 a$ and $4 b$ ). As used similarly in Marzelan Salleh's Puteri Gunung Ledang, the perfect 4th interval (in this case the $C$ note) is an intuitive inflection or 'note interference' in the scale. Further analysis also shows the pitch intervals (Example 4a and 4b) between the pelog scale and the one used in Dream share the same pitch intervals (number of semitones that separate one pitch from another). Therefore, these observations explain the audible result of Dream as still being able to evoke a gamelan-like sound world.

\section{Ex. 3: The six pitches used in Dream}

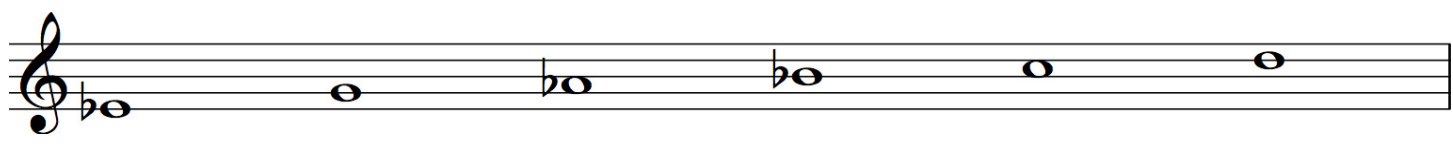

Ex. 4a: Scale used in Dream, with an added Perfect 4th. Numbers show the pitch interval (number of semitones between pitches)

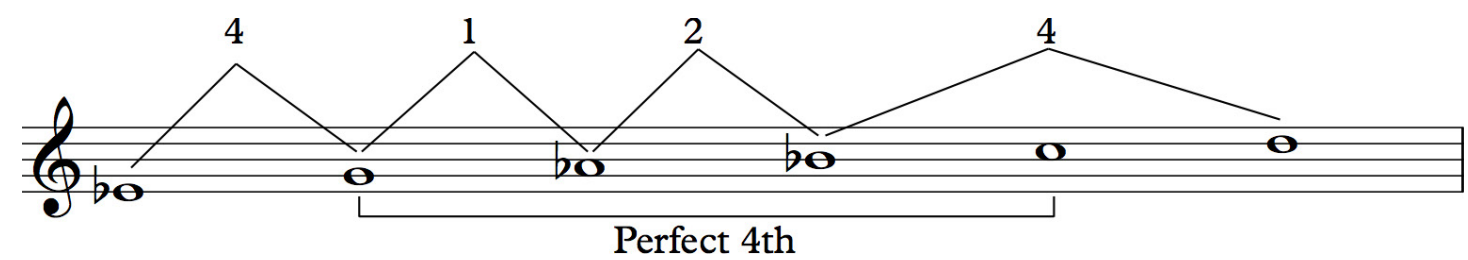


Intercultural Creativity and Exploration through Gamelanistic Elements...

Camellia Siti Maya Mohamed Razali • Marzelan Salleh

Ex. 4b: Pelog scale. Numbers show the pitch interval (number of semitones between pitches)

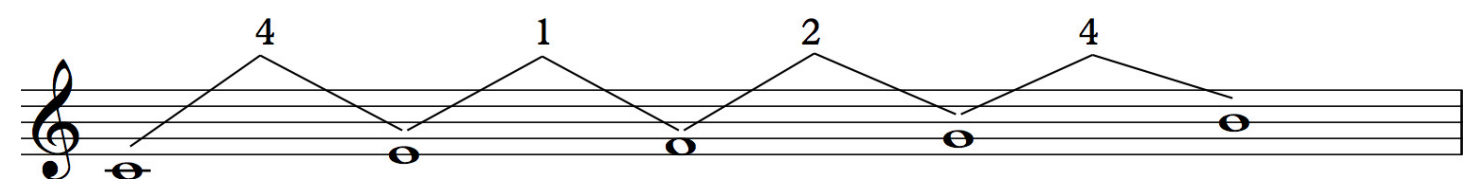

Dream is wholly made up of a single melodic line, although there are three harmonic chords in wide and closed spacing, which are repeated successively towards the end of the piece. These final chords are also strictly made up of the six pitches determined by John Cage (Figure 6).

Fig. 6: Chordal harmonies made up of the determined six pitches

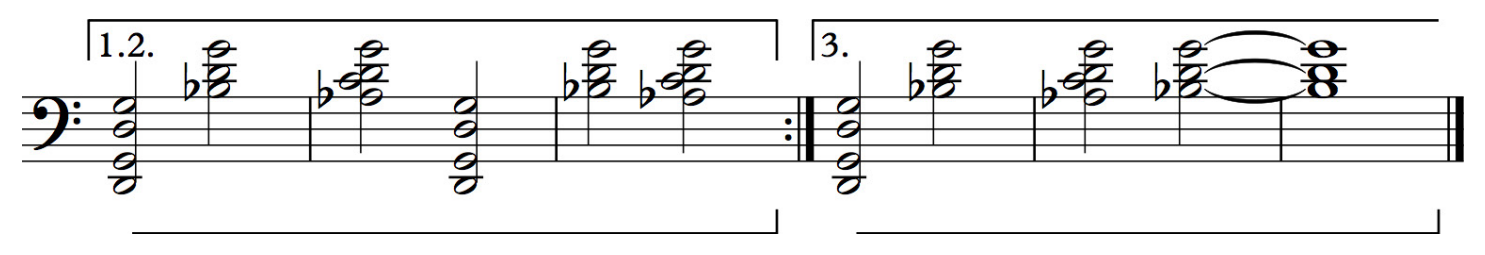

\section{The Concept of Intercultural and Outline of Musical Identity}

Any perceived cultural difference among humans as a result of an interaction or encounter is considered as intercultural. Whether it is a clash of clans or an adaptive assimilation, intercultural repercussions in art such as music brings to light newly found and innovative sound ideas. The initial concept of intercultural in our modern world has actually been around since the beginnings of the twentieth century, although it is not known when the expression intercultural music was first used. In those times, the western world's new discoveries and communication with the 'oriental' or 'exotic' side of their world, which many have never encountered before, brought upon a plethora of sound resources and different nuances. This new observation of orientalism led on to books 
questioning and challenging these terms or themes the western world has created or classified as a way of representation, or to differentiate or distinguish them apart from. Written discourses such as Edward Said's book entitled Orientalism describes the eastern world as based on the perspective the West has of its oriental counterpart, making it more of a post-colonial oppression (Said, 2003). The Western concept of different cultures or any irregularities in culture compared to theirs were stereotyped and typecast as lower standard. So, are the so-called intercultural creations are only 'westernized' visions of another culture?

Intercultural compositions are about the capacities of composing in an intercultural way considering the level of immersion of a composer in another culture. Intercultural in general definition is the integration of two or more different cultures. (Kimberlin \& Euba, 1995). The concept of intercultural can be implemented into many disciplines, and as for in the context of composition, intercultural music is defined when the composer of the music belongs to one of the cultures or traditional elements from their local ethnic or social context, and represented in the music (Euba, 1995).

Music can represent an identity and on the other hand of looking at it music can be asserting cultural difference (de Block \& Buckingham, 2007). Musical identity also includes choice of music, and favour in music, which are connected to own cultural background and personal history. Musical identity and musical choices do not necessarily directly link to taste but more to the cultural environment. For example, a person moving to a new foreign land might identify himself with their homeland's folk music, which is more significant when asked to present himself and his music overseas. In similarity, Marzelan Salleh as a composer who has been studying and living overseas for many years might have faced or experienced this phenomena and in a good turn has written works which may be termed as intercultural, raking in through time Malay nuances and sounds into his compositions until it has become his main style and own compositional voice. 
With these two solo piano pieces from two different composers coming from two different backgrounds, two different (musical) cultures, and two different personal histories; their representation of a sound scape, that is most likely referring to gamelan music is heard in both their compositions here. However, the outcome of both pieces is unalike and distinctive in their own right. The various aspects as stated above do influence the intercultural creativity of a composer. The same intercultural concept carried by two composers certainly will at most times produce different sounding results. Intercultural creativity most certainly is a by-product of ingenuity and personality.

\section{Gamelanistic Sound Elements}

Sounds of gamelan in a way can present other analytical aspects that would surpass the western analysis. The common musical terms of traditional western analysis of pitch, harmonic progression, and pulse could be replaced to describe the physical and sensual nature of gamelan's sonic experience. Pitch and tuning concepts actually vary between cultures (Kaiser, 2004). Instead, spectrum analysis of overtones to capture sonic experiences at certain points could be more suitable for gamelan music analysis to replace a traditional discussion of pitch. Musical elements such as harmonic progression or progression of chords through time, can be replaced with the concept of motion, which is patterning to any kind of parameters (Kaiser, 2004). The cyclic sonic concept of gamelan such as repetition is the physicality of gamelan. So instead, pulse can be used to discuss rhythmic concepts such as metre and beat (Kaiser, 2004). The spectral characteristics of gamelan instruments consist of several instruments, with different harmonic series compared to western instruments. Besides that, the modes and tunings, and timbral aspects of both gamelan instruments and western instruments are dissimilar. Nevertheless, both works discussed in this article looks into the ways both 
Intercultural Creativity and Exploration through Gamelanistic Elements...

Camellia Siti Maya Mohamed Razali • Marzelan Salleh

composers have used sonic hints and nuances of gamelan modes into their piano compositions.

\section{Conclusion}

Marzelan Salleh's and John Cage's music are both based on Western elements, but Marzelan Salleh's music intentionally derives from traditional source materials of gamelan music while John Cage has unintentional sound nuances of gamelan music.

Marzelan Salleh's compositional creativity in Puteri Gunung Ledang stems from his motivation to realize the musical variety and interchangeability between modern Western idioms and modal rhythmic figures of Asian music. As a cultural basis and to provide familiarity to traditional Malay roots, thematic materials and rhythms originating from traditional sources are employed in Puteri Gunung Ledang. Nevertheless, Marzelan Salleh's compositions are more concerned on the balanced flow of ideas between two different music principles rather than preserving cultural or traditional authenticity. As a result, Puteri Gunung Ledang employs Asian scales or modes while using Western forms and techniques of composing, thus resulting in a showcase of Malay idiomatic expressions linked with foreign technical elements. Marzelan Salleh's characteristic use of Asian melodies and intervals create an exotic and ancient quality towards his music

Gamelan elements are apparent in Puteri Gunung Ledang's harmony and polyphonic writings. Harmonically unusual, dissonance is almost absent in Puteri Gunung Ledang although using Western chord structures. He rather uses tonal centres and layerings as structural components for his music. Marzelan Salleh has transformed his compositional research into an original creative harmonic idiom. His unusual rhythmic combinations of Western variable metres with traditional irregular patterns of groups of five and seven lends another characteristic element of traditional sources. 
Intercultural Creativity and Exploration through Gamelanistic Elements...

Camellia Siti Maya Mohamed Razali • Marzelan Salleh

A study of Puteri Gunung Ledang will provide an understanding into the compositional processes of analyzing, deconstructing, and synthesis. In his search for an individual style, Marzelan Salleh has surpassed the levels of borrowing to re-creating traditional themes and towards applying the results into his work.

In the late 1930s of Cage's career, one can hear vague resonances of Balinese gamelan, subtly blending into a dreamy and wistful atmosphere. Dream, constitutes a simple single tones, and less conventional use of scales and modes otherwise deriving from rattles, chords, and gongs. The resonating tones by sustained pedals in the manner of ad libitum for the composition of Dream carries a flavor, which is melodious and wistful, accentuated by the bass' deep, melancholy line. It's an extremely haunting piece, static, meditative, and somewhat suspended in time containing both the hints of timbre and wisps of certain Asian sounds.

\section{Future Research}

Both composers approach to musical composition reflect a strong desire to reinterpret elements of traditional Asian music in contemporary musical terms. Their compositions often outline an intercultural approach in which Western and Asian elements constantly interact. While their creative experiments reflect a liberal approach that is generally open to the use of foreign, especially Western elements, they have constantly been seeking fresh means through which the essence of Asian musical tradition can be effectively captured in their compositions. Intercultural issues were certainly important elements of the compositions, nevertheless, what is most interesting in the pieces have nothing to do with matters of culture or race. The idea of interculturalism may in fact place borderless compositional opportunities on the composers. Marzelan Salleh and John Cage demonstrated a creative energy not defined by their heritage. So, while working within a predominantly Western idiom of musical expression, an 
Intercultural Creativity and Exploration through Gamelanistic Elements...

Camellia Siti Maya Mohamed Razali • Marzelan Salleh

intercultural synthesis of Western and Asian elements, they made sure of the use of traditional Asian elements in neither a superficial nor a simply symbolistic way.

On another note, it is time to move the intellectual discourses on modern traditional art music to substantial and detailed analysis. It is only through such critical studies that a proper understanding of these works can be developed. Materials generated from such studies will be of immense value to scholars as well as musicians who want to gain a more comprehensive insight not only into the Western art music tradition but its extension in the non-Western world.

Upon observation, composers infusing rhythms, melody and elements of traditional music receives positive responses from the audience. For example, familiar sounding pitches of gamelan or other traditional music, folk tune and clear rhythmic patterns will generally appeal to a wider audience reception.

\section{References}

de Block, Liesbeth, and David Buckingham. Rapping all over the world: Music, media and intercultural communication. Global children, global media, Palgrave Macmillan, London, pp. 177-194, 2007.

Jensen, Marc G. "John Cage, Chance Operations, and the Chaos Game: Cage and the" I Ching"." The Musical Times, 150, no. 1907, p.97-102, 2009.

Jo, Hye-Won. The Music of John Cage: Early Piano Compositions.

International Journal of Music and Performing Arts, American

Research Institute for Policy Development, 3(1), p.25-34, 2015.

Kaiser, Andrew. Sound as intercultural communication: A meta-analysis of music with implications for SETI. Leonardo, 37, no. 1, p.36-37, 2004. Accessed on 31 Jul 2019. 
Intercultural Creativity and Exploration through Gamelanistic Elements...

Camellia Siti Maya Mohamed Razali • Marzelan Salleh

Kimberlin, Cynthia Tse, and Akin Euba. Excerpt from the "Introduction" to Intercultural music. Vol. 1. Bayreuth African Studies, 1995.

Malm, William P. Music Cultures of the Pacific, the Near East, and Asia. USA: Prentice Hall Inc., 1996. 169p.

Said, Edward. W. Orientalism. USA: Penguin, 2003. 396p.

Wiggins, Trevor. An interview with JH Kwabena Nketia: Perspectives on tradition and modernity. Ethnomusicology Forum, Taylor \& Francis Group, vol. 14, no. 1, pp. 57-81, 2005. 